\title{
RESTORATIVE JusticE: A NEW PARADIGM FOR CRIMINAL JUSTICE POLICY
}

\author{
Donald J Schmid*
}

In this article, Donald Schmid reviews trends towards restorative justice across several common law jurisdictions, most notably New Zealand and the United States. He examines different models of restorative justice and concludes that, while none of these practices will completely eliminate the need for other, court-based criminal justice processes, they have a large number of practical and social advantages over more traditional approaches.

Several countries, including most notably New Zealand and Australia, have garnered international acclaim over the last decade for restorative justice initiatives in their criminal justice systems. In particular, the New Zealand invention of the "Family Group Conference" (FGC) for youth offenders has been hailed as a pioneering model of restorative justice. Other examples of restorative justice have been piloted in other countries.

But what is restorative justice? Restorative justice is a system or practice which emphasises the healing of wounds suffered by victims, offenders, and communities that are caused or revealed by offending conduct. With restorative justice, parties with a stake in a criminal offence (including the offender, the victim, and the communities of each) collectively resolve how to deal with the aftermath of the criminal act with an emphasis on repairing the harm from that act. Examples of restorative justice include FGCs, sentencing and peacemaking circles in North America, and victimoffender mediations in the United States, each of which are described below.

Criminal justice processes that are restorative share a number of characteristics that explain why they are effective in - among other things - reducing reoffending, increasing satisfaction rates, and preventing crime in the first place.

* Federal prosecutor with the United States Department of Justice. He was awarded an Ian Axford (New Zealand) Fellowship in Public Policy by the New Zealand Government in 2001. He is an Assistant United States Attorney and he is the Chief of the United States' Attorney's Office in South Bend, Indiana. He is also an Adjunct Professor of Law at the University of Notre Dame Law School, Notre Dame, Indiana, United States. 
Perhaps most important, restorative justice makes the actual victims of crime central participants in the response to the crime. FGCs in New Zealand are conferences in which victims are invited to meet offenders and their families, with the police and a justice co-ordinator present, to discuss the crime and what should happen as a result of the crime. Victims are thereby given a right (but are not obliged) to tell the young offender of the impact of the crime and to get their questions answered, face-to-face. Why were they victimised? Will they be victimised again? How will the offender put things right? Persons who have observed FGCs and other kinds of restorative justice conferences attest to how important this expression is not only for the victim but the offender and his or her family.

Critically, the involvement of the victim leads to a greater accountability from the offender. It is difficult for offenders to make excuses and to retreat behind a shell in the face of victims recounting the often devastating impact of the offence. Offenders more often express real remorse, which is a key step to their own journey away from crime and to the healing of the wounds suffered by victims.

Restorative justice works additionally because it gives new voices to victims, to offenders, and to community representatives. In this way, the participants - including even police - feel a greater sense of ownership in the process and of the outcomes produced by the process. This explains why researchers have found much higher levels of satisfaction with restorative justice processes than with traditional criminal justice in the courts. Victim and offender satisfaction rates in excess of $90 \%$ are not unusual.

Restorative justice programs are also a natural fit with community policing and police problemsolving, which have proven so effective in reducing crime rates in countries around the world. A key component of community policing is for the police to better understand the communities they serve. Restorative justice processes allow the police and other participants to understand in greater detail why a crime was committed in the first place. Police, working with community groups, can then use this information to target specific areas and types of offending with carefully tailored programs to reduce crime. In Wellington, New Zealand, police and the Wellington City youth justice co-ordinator have used information gathered from FGCs to target certain gang activity and truancy problems. The net effect has been an impressive two-thirds reduction in crime by youth offenders in Wellington City since 1996.

Another key to the effectiveness of restorative justice is its ability to accommodate cultural, ethnic, and religious diversity. FGCs and other kinds of restorative justice conferences, for example, can be held almost anywhere. The ability to conduct a conference at a sacred place or at the offices of a community group (with due deference to the view of the victim as to venue) can make an important difference. Even if held at a governmental office, restorative justice procedures are flexible enough to allow prayer and other types of cultural and religious accommodations. 
Consensus decision-making is also very important. The hallmark of restorative justice is collaboration among those parties with an interest in the criminal offence, including victims, offenders, families of victims and offenders, community groups, and the police. Decisions are reached in FGCs in New Zealand and restorative justice programs elsewhere as a result of the conference groups coming to better understandings and achieving collective agreement as to how the injuries that were caused and revealed by the crime can best be healed.

Because they often reveal a deeper understanding of what is needed to reintegrate the offender into the community and to restore the victim, restorative justice conferences frequently lead to the greater use of community resources (including drug and alcohol counselling and alternative education programs). In this way, restorative justice seems better at building communities and resources within the community than traditional court processes.

Restorative justice is not a panacea. Nor can it supplant completely conventional criminal court processes. But in New Zealand and elsewhere, it is a tool that has repeatedly proven to be effective.

\section{THE CONCEPT OF RESTORATIVE JUSTICE}

A well-accepted definition of restorative justice has proven elusive. Many authors have resorted to indicating what restorative justice is not. In these instances, restorative justice is usually set off against "retributive justice". ${ }^{1}$ Others have indicated a number of principles by which restorative justice is characterised. ${ }^{2}$

The lack of a conclusive definition may be the result of the failure of scholars to date to produce an underlying theory to explain and justify restorative justice practices. Nevertheless, we have gained enough experience and enough has been written to venture at least a working definition of restorative justice:

Restorative justice is a system or practice which emphasises the healing of wounds suffered by victims,

offenders, and communities that are caused or revealed by offending conduct.

Another useful definition of restorative justice is: "Restorative justice is a process whereby parties with a stake in a specific offence collectively resolve how to deal with the aftermath of the offence and its implications for the future". ${ }^{3}$

1 See Kathleen Daly "Revisiting the Relationship between Retributive and Restorative Justice" in Heather Strang and John Braithwaite (eds) Restorative Justice: Philosophy to Practice (Ashgate, Aldershot, 2000) 34. "The oppositional contrast between retributive and restorative justice has become a permanent fixture in the field".

2 See, for example, Allison Morris and Gabrielle Maxwell "Restorative Conferencing" in Gordon Bazemore and Mara Schiff (eds) Restorative Community Justice (Anderson Publishing Co, Cincinnati, 2001) 174-175, and Tony F Marshall Restorative Justice: An Overview (HMSD, London, 1999) 5.

3 Tony F Marshall "Restorative Justice: An Overview" (HMSD, London, 1999) 5. 
Under either definition, restorative justice focuses on the harms that are caused by offending conduct - harm to the victim personally, harm to the offender him or herself, and harm to the community as a whole from the wrongful conduct. ${ }^{4}$ As suggested by its label, restorative justice seeks to restore or repair damage caused by the offender's conduct. ${ }^{5}$

To be sure, restorative justice constitutes a way of thinking about crime and the responses to it that are different from conventional western approaches to crime. ${ }^{6}$ It focuses on the harm caused by the crime, repair of that harm, and reduction of future harm by preventing future crime. ${ }^{7}$ Restorative justice requires offenders to take responsibility for their actions and for the harm they have caused. ${ }^{8}$ It seeks redress for victims, recompense by offenders, and reintegration of both victims and offenders within the community. ${ }^{9}$

Howard Zehr has written: ${ }^{10}$

Crime is a violation or harm to people and relationships.

The aim of justice is to identify obligations, to meet needs and to promote healing. The process of justice involves victims, offenders and community in an effort to identify obligations and solutions, maximising the exchange of information (dialogue, mutual agreement) between them.

In other words, crime violates people. Violations always create obligations. Justice should involve victims, offenders and the community in search to identify needs and obligations so that things can be made right (so far as possible).

Efforts to articulate a satisfactory theory to underlie the diversity of restorative justice programs and practices that have developed in recent years have proven to be as difficult as putting forward an accepted definition of restorative justice. ${ }^{11}$ However, one of the better attempts to posit an

4 Daniel Van Ness and Karen Heertderks Strong Restoring Justice (Anderson Publishing Co, Cincinnati, 1997) 31 .

5 Tony F Marshall "Restorative Justice: An Overview" (HMSD, London, 1999) 7.

6 Daniel Van Ness and Karen Heertderks Strong Restoring Justice (Anderson Publishing Co, Cincinnati, 1997) 42.

7 Restoring Justice, above.

8 Restoring Justice, above.

9 Restoring Justice, above.

10 Howard Zehr "Rethinking Criminal Justice: Restorative Justice" (May 1995) 9, reprinted in Judge F W M McElrea (ed) Re-thinking Criminal Justice (Vol 1, Legal Research Foundation, Auckland, 1995).

11 See Kathleen Daly and Russ Immarigeon "The Past, Present, and Future of Restorative Justice: Some Critical Reflections" (1998) 1 Contemporary Justice Review 31 (restorative justice "does not yet have a coherent paradigm"). 
underlying theory was from an American law professor, Erik Luna, while he was a visiting lecturer at Victoria University in Wellington. In his lecture entitled "Reason and Emotion in Restorative Justice", Luna traced the development of western penal philosophy as applied to juveniles, a philosophy that vacillated between the "treatment" sanctioning model and the "punishment" sanctioning model.

The treatment model views the juvenile offender as "sick" in need of treatment and health services. ${ }^{12}$ Under this model, the juvenile offender is not deemed accountable for his actions and instead his "sickness" is considered the precipitating cause of the offending. Under the treatment model, the state takes possession of the child for his own good and seeks to rehabilitate him into a law-abiding member of society. This would typically involve involuntary counselling and medical care, and in some instances institutionalisation in a residential "treatment" facility. ${ }^{13}$

In response to strong perceptions of the failure of the treatment model, many jurisdictions including in America shifted to a youth court system grounded in the "just desert" theory of justice. $^{14}$ The punishment model of juvenile justice places its emphasis on determining guilt and then punishing the offender for his or her moral blameworthiness. ${ }^{15}$ The central actors are legal professionals, including judges and lawyers, who are involved in an adversarial contest between the state and the defendant. Once guilt is established, then the court imposes punishment in proportion to the gravity of the crime. ${ }^{16}$

In his article, Luna sets out three basic principles and the five sub-principles of "restorative sanctioning". ${ }^{17} \mathrm{He}$ then measures the "treatment" and "punishment" sanctioning models against these principles. Luna describes the basic principles of restorative justice or the restorative sanctioning model as follows: ${ }^{18}$

Restorative justice incorporates three basic principles in its approach to sanctioning. First, crime is not just an act against the state but against particular victims and the community in general. Offending, then, is primarily a breach of human relationships and only secondarily a violation of the law. As such, the community, family members, and supporters, rather than the state and its justice machinery, are considered the locus of crime control. Toward these ends, the restorative model seeks the active

12 Erik Luna "Reason and Emotion in Restorative Justice", paper provided to author, (2001) 9.

13 Luna, above, 9.

14 Luna, above, 10

15 Luna, above, 9.

16 Luna, above, 9.

17 Luna, above, 4-6.

18 Luna, above, 4. 
participation of victims, families, and community representatives to address the causes and consequences of offending.

Second, the primary aim of this approach is making amends for the offending, particularly the harm caused to the victim, rather than inflicting pain upon the offender. Accountability is defined as recognising the wrongfulness of one's conduct, expressing remorse for any resulting injury, and taking actions to repair the damage done by the offending. Crime creates positive obligations, this approach argues, that require affirmative action on the part of the offender.

Finally, restorative justice envisions a collaborative sanctioning process involving all stakeholders concerned with the offender and the offence. The central feature is largely uninhibited dialogue among the parties, allowing all present to express their emotions and ideas in an open forum. Through discussion and deliberation, restorative sanctioning contemplates mutual agreement and the steps that must be taken to heal the victim and the community, as well as a plan to confront the factors contributing to the offender's conduct and facilitate his development as a law-abiding citizen.

The first of the sub-principles is inclusion, or the notion that parties with a stake in the criminal offence should participate in the process that responds to the offence. ${ }^{19}$ The second sub-principle is voluntariness, or the idea that a party is involved in the sanctioning process by virtue of his own free choice. Included in this sub-principle is the ability to choose to accept or reject a particular outcome. ${ }^{20}$ The third sub-principle is that the participants, most notably victims and offenders, are entitled to support during this sanctioning process. ${ }^{21}$ This third sub-principle reinforces the first two principles of being included in the process of decision-making and being included without improper coercion. The fourth sub-principle, as articulated by Luna, is the parties' ability to control to some extent the very process by which decisions are reached. Stated differently, stakeholders in the restorative process must have the ability to shape the process to some extent. ${ }^{22}$ The last subprinciple is freedom of discourse among all participants. As Luna notes, uninhibited conversation ensures a level of ownership in the process and its outcome. ${ }^{23}$

Using these principles, it is easy to see just how different the restorative justice sanctioning model is from the treatment and punishment models. Neither the treatment nor punishment models are inclusive. The treatment model singularly focuses on the offender and his rehabilitation. Victims, their supporters, and community members are excluded from the process as largely

19 Luna, above, 5.

20 Luna, above, 9.

21 Luna, above, 5-6.

22 Luna, above, 6.

23 Luna, above, 9. 
irrelevant to the treatment of the offender. ${ }^{24}$ Similarly, the punishment model focuses on the state and the defendant in this court-centered form of justice. ${ }^{25}$ The victim, community representatives, and family members are largely excluded from the process.

With respect to the other principles as well, the treatment and punishment models fall far short of the restorative sanctioning model. As Luna stated: ${ }^{26}$

Both models exclude parties with important interests in the sanctioning process; reject the concept of voluntary participation; deprive the juvenile of important supporters; place process control solely within the ambit of professionals; prevent free dialogue among stakeholders; and thwart the pivotal stages of constructive censure, genuine remorse and stakeholder acceptance.

\section{WHAT HAS FUELLED THE RESTORATIVE JUSTICE MOVEMENT?}

The restorative justice movement, if it can properly be called that, has gained strength or impetus from a number of different sources. These include: the movement towards increased rights for victims in the criminal justice process; alarm over increasing and high rates of incarceration, particularly among indigenous or minority populations; the movement towards greater community involvement in crime prevention; and concern about recidivist offending.

In the late 1960's and in the 1970's, many in the United States became concerned about the lack of any formal or express rights belonging to victims of crimes. ${ }^{27}$ Concomitantly, many perceived an imbalance in the rights belonging to the accused and the rights of crime victims. ${ }^{28} \mathrm{~A}$ victims' rights movement thereby emerged. In 1982, for example, the President of the United States created a Task Force on Victims' Rights. That Task Force recommended a constitutional amendment for victims' rights. ${ }^{29}$ Shortly thereafter, in 1982, Congress passed legislation allowing victims to provide victim impact statements describing their experiences as victims and the costs incurred as crime victims. ${ }^{30}$ Several persons have recognized that part of the impetus towards restorative justice programs was the victims' rights movement. ${ }^{31}$

24 Luna, above, 9-10.

25 Luna, above, 10-11.

26 Luna, above, 11.

27 John W Stickels "Victim Impact Evidence: The Victims' Right That Influences Criminal Trials" (2001) Texas Tech Law Review 231, 235.

28 Stickels, above.

29 Terry Carter "Righting Victims' Rights" (2000) 86 ABA Journal 24.

30 Stickels, above, 236-237.

31 See, for example, Joan W Howarth "Toward the Restorative Constitution: A Restorative Justice Critique of Anti-Gang Public Nuisance Injunctions" (2000) 27 Hastings Const L Q, 717, 720. 
Over and above concerns regarding the plight of crime victims, many have advocated for restorative justice because of their view that incarceration rates are too high and too many people are being sent to prison. Father Jim Consedine, to take just one example, has argued vehemently that New Zealand imprisons far too many people at overwhelming costs. ${ }^{32}$ The same criticism is frequently levelled at the United States, which also has a high incarceration rate.

Others have expressed concerns about recidivist offending. Statistics compiled by the New Zealand Ministry of Justice, for example, show that an astounding $80 \%$ of persons imprisoned in New Zealand are re-convicted within two years of their release from prison. ${ }^{33}$ There is a widely held view that the criminal justice system can and must do better. As the Chief District Court Judge of New Zealand, David Carruthers, recently said: ${ }^{34}$

The reality is that our conventional system of criminal justice often does not work. It aims to deal with crime dispassionately without reference to emotion. In doing so, it fails to engage offenders and the victims of offences. It fails to stimulate any sense of respect for themselves or each other. Instead, it gives predominance to the needs of professionals who represent the state. Moreover, the adversarial nature of the system creates 'a hostile environment where concern for mutual respect is replaced with the desire for victory in a pure winner-take-all scenario.' Neither of these tendencies is helpful for the victim or offender. Despite the best efforts and intentions of judges, counsel and court staff, the conventional system often fails to provide victims or offenders with meaningful justice.

Finally, "religion and moral theory still provide strong backgrounds for restorative justice". ${ }^{35}$ From this perspective, restorative justice places an appropriate emphasis on offender accountability but at the same time strives for greater healing. The National Conference of Catholic Bishops in the United States has specifically endorsed the move to restorative justice practices. The Bishops stated in a November 152000 text: ${ }^{36}$

An increasingly widespread and positive development in many communities is often referred to as restorative justice. Restorative justice focuses first on the victim and the community harmed by the

32 Jim Consedine Restorative Justice: Healing the Effects of Crime (Ploughshares Publications, Lyttleton, 1995) $28-30$.

33 Ministry of Justice Recidivism Patterns For People Convicted in 1995 (Ministry of Justice, Wellington, 2001) 9 .

34 Chief District Court Judge David Carruthers "Restorative Justice, With Reference To Experience In New Zealand" $16^{\text {th }}$ Biennial District and County Judges' Conference, Adelaide, paper provided to the author, (2001) 4.

35 Leena Kurki "Restorative and Community Justice in the United States" (2000) 27 Crime and Justice 235.

36 National Conference of Catholic Bishops of the United States "Responsibility, Rehabilitation, and Restoration: A Catholic Perspective on Crime and Criminal Justice" (United States Catholic Conference, Washington, 2000) 20. 
crime, rather than on the dominant state-against-the-perpetrator model. This shift in focus affirms the hurt and loss of the victim, as well as the harm and fear of the community, and insists that offenders come to grips with the consequences of their actions. These approaches are not "soft on crime" because they specifically call the offender to face victims and the communities. This experience offers victims a much greater sense of peace and accountability. Offenders who are willing to face the human consequences of their actions are more ready to accept responsibility, make reparations, and rebuild their lives.

\section{FAMILY GROUP CONFERENCES}

Prior to 1989, New Zealand applied a "welfare" model to youth care and protection and youth justice. That is, issues regarding endangered children or juvenile misconduct were referred to professionals including social workers at the Department of Social Welfare. These professionals would make recommendations to the courts, which would then decide what should happen to or for the child. ${ }^{37}$ The statutory basis for this model was the Children and Young Persons Act of 1974. ${ }^{38}$ Under this model, children were in many cases removed from their families.

In the 1980 's, there was a growing concern that removal of children from their families was destabilizing and otherwise harmful. ${ }^{39}$ "New Zealanders had reached the view that the existing youth justice system was a complete failure under the Children and Young Persons Act 1974." 40

Many Maori in New Zealand in particular voiced their concerns that too many Maori children were being removed from their families and that the processes by which child welfare and youth justice decisions had been made were inimical to Maori traditions and values. ${ }^{41}$ The removal of children from Maori families upset many because of the particular importance of kinship and descent lines in Maori culture. ${ }^{42}$

Simultaneously, the treatment of youth offenders who had been placed in residences became a public issue in New Zealand. ${ }^{43}$ Part of the issue was the use of prolonged incarceration in the name

37 Joe Hudson, Allison Morris, Gabrielle Maxwell, and Burt Galaway Family Group Conferences: Perspectives on Policy and Practice (Federation Press, Sydney, 1996) 20-22.

38 Hudson, Morris, Maxwell, and Galaway, above, 20.

39 Hudson, Morris, Maxwell, and Galaway, above, 22.

40 Judge Carolyn Henwood "The Children Young Persons and Their Families Act 1989: The New Zealand Situation 1997 - A Judicial Perspective" paper presented to seminar on "Children and the Criminal Law", Judicial Commission of NSW, 1997, 2.

41 Neil Cleaver "Another Arm of the Bureaucracy?" (1995) Social Work Now 1, 7.

42 Hudson, Morris, Maxwell, and Galaway, above.

43 Hudson, Morris, Maxwell, and Galaway, above, 23. 
of child welfare. ${ }^{44}$ "Too many young people were in custody with very little differentiation between those who were in the need of care and protection and those who were committing crimes". ${ }^{45}$ In summary, the "existing legislation had become culturally and politically unacceptable for New Zealand society and reform was required". ${ }^{46}$

As a result, a Children and Young Persons Bill was introduced in Parliament in the mid-1980's. The Bill was referred to a select committee until 1987. At that time, a new Minister of Social Welfare directed that a review of the Bill be performed by the Department of Social Welfare with the provision that the Bill be made more culturally sensitive and accommodating to the tangata whenua (indigenous people). The Minister also directed that that the Bill involves parents and family groups in developing solutions to youth problems. ${ }^{47}$ These directions were based on public submissions concerning, and objections to, the 1986 Bill. $^{48}$

Neil Cleaver has described the working party's efforts to address public concerns including the concern for greater cultural sensitivity: ${ }^{49}$

In its report of December 1987, the working party on the Bill explained that instead of conducting a

"piecemeal analysis" of the Bill, it had:

... reviewed the basic assumption and intention underlying the Bill and endeavoured to develop proposals which were responsive to public concerns as to how those assumptions have been expressed. Particular attention was paid to the need to reflect in legislation the principles and spirit of the Treaty of Waitangi.

One of the key principles that guided the working party was that:

The Bill must involve parents, family groups, whanau, hapu and iwi in developing solutions to problem situations.

The working party saw this principle as overcoming what they perceived to be the monocultural nature of the Bill. In their view family/whanau involvement in some way implied that Maori values and

44 Hudson, Morris, Maxwell, and Galaway, above.

45 Judge Carolyn Henwood "The Children, Young Persons and Their Families Act 1989: The New Zealand Situation 1997 - A Judicial Perspective" paper presented to seminar on "Children and the Criminal Law", Judicial Commission of NSW, 1997, 2.

46 Judge Henwood, above, 3.

47 Hudson, Morris, Maxwell, and Galaway, above, 24-25.

48 Hudson, Morris, Maxwell, and Galaway, above.

49 Neil Cleaver "Another Arm of the Bureaucracy?" (1995) 1 Social Work Now, 7 available at $<$ http://www.cyf.govt.nz $>$. 
cultural practices would be incorporated into the way in which care and protection and offending of young people was addressed.

In 1989, a substantially modified Bill was introduced in Parliament. This draft legislation proposed the use of FGCs to deal both with care and protection for children and with youth crime. That Bill was passed as the Children, Young Persons and Their Families Act of 1989.

Several scholars have written that the Children, Young Persons and Their Families Act of 1989 and FGCs in particular were based on and incorporated Maori concepts and traditions of justice. ${ }^{50}$ But no one has been able to cite any concrete evidence that meetings (hui) along the lines of FGCs were used by Maori prior to European colonization or in the early 20th century. Rather, the implementation of the FGC in the 1989 Act was a product of objections to professional "care and protection" teams deciding the fate of children. In the place of professional teams, the responsibility for decision-making was given to families (whanau) and extended families (hapu).

The "foundation stone" of the 1989 Act is the FGC. ${ }^{51}$ Chief District Court Judge David Carruthers (also the former Principal Youth Court Judge) has identified the FGC as a New Zealand invention and its "gift to the world". 52

In a New Zealand FGC, a youth justice co-ordinator invites the victim of the criminal offence to meet with the offender and the offender's family. Police also attend the conference. After introductions, the conference is commenced most often by the police reading a "statement of the facts", which describes the criminal offence and basic background information about the youth offender. The offender is then asked if he or she denies or admits those facts. If the offender agrees to the facts of the offence (or at least the core portion of them), then the victim is asked to speak about the impact the offence has had on him or her. On those occasions when the victim is unable or unwilling to attend in person, the youth justice co-ordinator may read a letter or other kind of statement from the victim recounting the impact of the criminal offence on the victim. Frequently, statements by the victim are followed by an apology or some expression of remorse by the offender. The conference participants then discuss collectively and sometimes with emotion what should be done to repair the harm to the victim (including the payment of restitution) and what the offender

50 See, for example, Chris Cuneen "Community Conferencing and the Fiction of Indigenous Control" (1997) 30 Australian and New Zealand Journal of Criminology 292, 293.

51 Mike Doolan "The Family Group Conference - 10 Years On" (1999) International Institute for Restorative Practices <http:www.restorativepractices.org/pages/vt_doolan.html $>$ 2, and see also Judge Carolyn Henwood "The Children Young Persons and Their Families Act 1989: The New Zealand Situation 1997 - A Judicial Perspective" paper presented to seminar on "Children and the Criminal Law", Judicial Commission of NSW, 1997, 13. "The jewel in the crown of our Act is the 'Family Group Conference'".

52 Remarks by Chief District Court Judge David Carruthers, Wellesley Club Luncheon, Wellington, New Zealand, June 6, 2001. 
should do in order to be held accountable for the offence. After a suitable discussion period, the offender is left alone with family members to discuss a suitable plan.

Once the family has had sufficient time to caucus privately, then the entire group reconvenes to hear of the proposed FGC plan from the family and the offender. The proposed plan is discussed and frequently negotiated by the parties including the police and the victim. If a collective agreement is reached, the plan is recorded in writing by the justice co-ordinator. If criminal charges had been presented in court, then the FGC plan is presented to the court for approval.

Most persons who are familiar with the FGC process in New Zealand would agree that the youth justice co-ordinator is a key participant in the process. Until recently, only a small number of youth justice co-ordinators had been interviewed by researchers to obtain their views on certain aspects of the FGC process. But no effort had been made to survey all youth justice co-ordinators in New Zealand concerning their views on FGCs and youth crime in general. The author, with the Department of Child, Youth, and Family Services (CYFS) National Co-ordinators Manager, undertook in May - June 2001 to survey all of the youth justice co-ordinators in New Zealand. Written questionnaires were sent to all co-ordinators or supervisors who were currently employed at CYFS and who had conducted FGCs. About $75 \%$ of co-ordinators responded to the survey.

Among other things, the survey confirmed that family group conferencing is working for youth offenders and has further identified what makes FGCs effective. More than $92 \%$ of co-ordinators believed that FGCs were effective overall. About $8 \%$ of co-ordinators believed that FGCs were only sometimes effective. No co-ordinators believed that FGCs were not effective at all.

About half of the responding co-ordinators believed that the victim's attendance and input at the FGC was what makes the FGC effective. The importance of the victim's participation was echoed by the co-ordinators' comments about the impact of victim non-attendance. The vast majority of co-ordinators believed that non-attendance by the victim, whatever the reason, dramatically reduced the impact of the FGC on the offender and hence the FGC's effectiveness. Most felt that the absence of the victim made it difficult to demonstrate to the offender the harm from the criminal conduct and, as a result, made it easier for the offender to remain detached from and unmoved by the process. Put another way, the victim's non-attendance undermined the effort to hold the offender accountable.

Equally important to making FGCs effective was thorough preparation, including personal visits with families of the offender and victims, by the justice co-ordinator prior to the convening of the FGC itself. Other less frequently noted keys to making FGCs effective were: vigilant monitoring and follow-up of the FGC plan or agreement; the family of the offender taking responsibility for, and supporting, the young offender; and requiring the offender to take responsibility for his or her criminal conduct.

Co-ordinators had many ideas for making FGCs more effective more often. The most frequently indicated ways to improve FGC effectiveness was to allow more time to convene the 
FGC and to have better resources and programs available to the young person who had offended. Other suggestions for improving the effectiveness of conferences included limiting the number of FGCs held for an individual offender and improving the resources available to offenders.

While a significant number of co-ordinators believed that victim needs were met "well" or "very well" (a little more than 25\%), many co-ordinators believed that victims' needs were met only in certain situations. The most frequently cited victim need not met by the FGC process was full restitution for victim losses. Even though the monetary needs of victims were not well met, coordinators believed that victim needs of having a voice in the process, of telling their stories, and of venting their feelings were significant needs met by the FGC process. Only about $4 \%$ of coordinators felt that victim needs were "not met" or were "poorly met" by the process overall.

Surveyed co-ordinators almost all felt that effective steps could be taken that would avoid victims being re-victimised at the FGC. Co-ordinators cited the ability of victims to have support persons at the conference as one such measure. Other protective measures included careful preparation in advance of the conference of both offenders and victims to ensure that the rights of victims were well understood and that victim expectations were realistic. Co-ordinators also cited the presence of police as well as the control exerted by the co-ordinator at the conference as steps that helped ensure that victims were not intimidated or otherwise re-victimised at the FGC. Finally, co-ordinators frequently cited the veto power that victims had over the FGC plans or agreements as a way for victims to avoid being re-victimised.

Another measure of the success of FGCs is how often FGC plans or agreements were successfully completed by young offenders. Co-ordinators were asked in what percentage of cases with agreed-upon FGC outcomes were FGC agreements "entirely or almost entirely fulfilled by the young person". The responses revealed that, on average, FGC agreements or plans were successfully fulfilled in over $80 \%$ of cases.

A large percentage of co-ordinators (about $88 \%$ ) believed that group conferences could be used effectively with adult offenders. Some co-ordinators believed that use of such conferences would be even more successful with adults than with young persons while others believed that group conferences could only be used successfully with some adult offenders. Only a small number (4\%) felt that group conferences could not be used effectively with adults. About $8 \%$ were simply not sure.

As part of the survey, co-ordinators were asked what they thought the most pressing youth crime problems were in New Zealand today. The number one crime problem cited - by a large measure - was drug and alcohol use and addictions. More than half of the responding co-ordinators (57\%) viewed drug and alcohol abuse and addictions as one of the most pressing youth crime problems today in New Zealand. The next most frequently cited youth crime problem was violent offending by New Zealand youths. Also cited by numerous co-ordinators as problems were: 
burglary or home invasion crimes by young persons, breakdowns in family structures, single parent families, lack of parental supervision, violent culture, and poor parenting.

\section{ADULT CONFERENCING IN NEW ZEALAND}

An early proponent of extending restorative justice processes to adult offenders in New Zealand was District Court Judge FWM McElrea. In 1994, at a judges' conference, McElrea proposed the idea of adapting youth justice processes to adult criminal courts. ${ }^{53}$ Other calls for the extension of restorative justice to adult offenders in New Zealand followed. ${ }^{54}$

In 2000, a pilot program that extended restorative justice conferencing to adult offenders was run in Waitakere (west of Auckland), New Zealand. This pilot was established by a partnership between the Restorative Justice Trust and the Methodist Mission Northern. The Restorative Justice Trust was established in 1999 to study, promote, and refine restorative justice practices in New Zealand.

This program involved cases referred from the Waitakere District Court during the period from April 1, 2000 until September 30, 2000. Any participant in a criminal case could suggest a referral to the pilot program for a restorative justice conference. The criteria for referral were that:

- $\quad$ there was a direct victim;

- the offence had a maximum sentence of at least two years imprisonment;

- $\quad$ the offender had admitted guilt;

- $\quad$ there was essential agreement about the facts underlying the case.

The Court could either approve or disapprove of a referral. Once approved by the court, the administrator of the pilot program appointed a facilitator. The facilitator was responsible for contacting both the victim and the offender to see if they were agreeable to proceeding with a restorative justice conference. If they were, a conference was convened to bring together the offender and victim along with police, probation officers, lawyers, and supporters of both victim and offender. The focus of the conference was to discuss the criminal offence and how amends could be made. The facilitator was then responsible for writing a report of the conference and the conference agreements, which was then forwarded to the court. Although the report was not binding on the court, the court would then consider the report in conjunction with deciding the disposition of the case and the sentence to be imposed, if any, on the offender.

53 Bowen, Boyack, and Hooper New Zealand Restorative Justice Practice Manual (2000) 18.

54 See Jim Consedine Restorative Justice: Healing the Effects of Crime (Ploughshares Publications, Lyttleton, 1995) 28-30. 
During the pilot period, 42 cases were referred to the program. Restorative justice conferences were held in 22 of the 42 referred cases. In the remaining 20 cases, either the offender or victim declined to participate in the conference or the offender was deemed unsuitable.

In June 2000, the New Zealand Government announced NZ\$4.8 million in funding to introduce restorative justice conferences for adult offenders. In September 2000, the government announced that this pilot program would be conducted in four District Courts in Auckland, Waitakere, Hamilton and Dunedin.

This pilot restorative justice program is used for persons who have committed offences for which the maximum sentence is at least two years imprisonment. A conference is conducted only with the voluntary consent of the offender and of the victim. Conferences are adjourned and supervised by two co-facilitators, who are paid for their service. A written report from the conference is prepared and forwarded to the sentencing court.

The programme began receiving referrals in the latter part of 2001. Four co-ordinators, from the Department of Courts, were selected for each of the four district courts that are included in the pilot. Facilitators for the conferences were selected and trained in 2001. Training consisted of four days of training and evaluation as to whether the prospective facilitators were ready to adjourn conferences.

Initially, the pilot programme had expected to handle up to 1200 cases per year. To date, through March 2003, 740 cases had been referred for conferencing. 256 cases had actually been conferenced. Evaluations of this pilot conference programme for adults are being done at this time.

\section{PROJECT TURNAROUND IN TIMARU, NEW ZEALAND}

Project Turnaround is a community-based diversion scheme that was begun in Timaru, New Zealand in 1997. Under this program, certain offenders who have admitted guilt and have shown remorse are diverted from the court after an initial appearance before a judge. If there is victim consent, a diversion meeting or conference modelled in part on FGCs from the youth justice area is convened with an emphasis on community rather than family.

To represent the community, two members from a panel of volunteers are present at the conference along with a police representative. Both the offender and victim are encouraged to bring supporters to the conference. At the conference, the police read the summary of facts (which describes the criminal offence) and the offender must admit his or her guilt. The victim is invited to describe the impact of the crime and his or her feelings. Queries are made to the offender as to why the offence was committed and what contributed to it.

Thereafter, the Project Turnaround conference turns to the question of how to deal with the offending. The victim and the offender are asked to suggest ways to deal with the offending and a plan to address the offence is put together. Before the end of the conference, the offender is asked to sign a contract in which she or he agrees to do certain things within set time frames. 
Critically, the victim has the final say on whether the plan should go ahead or the matter should be returned to the court. Very few victims, however, have elected to return the matter to court.

After the conference, the offender's progress on the plan is monitored to assure completion. If the plan is not completed, the matter is referred back to the court. If the plan is completed, the criminal charges are dismissed and a criminal conviction with respect to the matter is avoided. Less than $10 \%$ of matters are referred back to the court because the offender has failed to complete the agreed-upon plan.

In 2000, Project Turnaround received an International Community Justice Award in London, England for "implementation of an outstanding community-based project which places the victim's views at the heart of the process and which has contributed significantly to reducing reconviction rates while retaining public confidence". ${ }^{55}$ Project Turnaround continues today.

\section{RESTORATIVE JUSTICE IN OTHER JURISDICTIONS}

\section{A Australia}

Conferencing, adapted from the New Zealand family group conferencing model, was introduced into the Australian criminal justice system in the early 1990's. ${ }^{56}$ For example, in 1991 police in the city of Wagga Wagga, New South Wales adopted portions of the New Zealand conferencing idea but in the form of conferences coordinated and facilitated by police officers. ${ }^{57}$ Police in other Australian locations in the Australian Capital Territory (ACT) and were tried on a pilot basis in Western Australia, the Northern Territory, Queensland, and Tasmania also experimented with conferencing organised by the police. Other applications of the conferencing idea have been tried in schools and workplaces in New South Wales and Queensland beginning in 1994.

Different jurisdictions handle conferencing in slightly different ways. In the ACT, conferencing is run by the police; in New South Wales, South Australia, Western Australia, and Queensland it is run by justice authorities; and in Victoria it was run by a church body. There are three jurisdictions in Australia (Western Australia, Queensland, and the ACT) where restorative conferencing is being used with adult offenders. ${ }^{58}$ Recently, the New South Wales Attorney-General's Department proposed a two-year pilot programme of community justice conferencing for adult offenders. ${ }^{59}$

55 Ministry of Justice Justice Matters (Ministry of Justice, Wellington, 2000) 16.

56 See Australian Institute of Criminology "Restorative Justice: An Australian Perspective" (2001) and also see, Chris Cuneen "Community Conferencing and the Fiction of Indigenous Control" (1997) 30 Australian and New Zealand Journal of Criminology 292, 293.

57 Australian Institute of Criminology "Restorative Justice: An Australian Perspective" (2001)

58 Heather Strang "Restorative Justice Programmes in Australia" (2001) 4, 28-29 $<$ http://www.aic.gov.au/crc/reports/strang/index.html $>$.

59 See "Community Justice Conferencing for Adult Offenders Discussion Paper - Model" (2001) 1. 
A principal objective of conferencing in Australia is to diversion from the conventional criminal justice system. But the prerequisite for diversion is an admission of guilt. Conferences in Australia most often last one or two hours, are attended by the victims and their supporters, the offenders and their supporters, and other interested parties. The coordinator of the conferences attempts to steer the discussion toward condemnation of the criminal act while trying not to condemn the criminal. Offenders are asked to explain what happened during the criminal act and what they think should be done as a result of the act. The victims and others are asked to describe the physical, financial and emotional harms that have resulted from the criminal act. This discussion may lead to an apology being given to the victim. A plan future action is decided upon and agreed to by key participants in the conference. The plan may include the offender making restitution to the victim, doing work for the victim or the community, or any other undertaking the participants may agree upon. It is the responsibility of the conference participants to determine the outcomes that are most appropriate for these particular victims and these particular offenders.

\section{B Canada}

Circle sentencing is a type of restorative justice conferencing that is used in Canada. In 1992, Yukon Judge Barry Stuart convened the first circle conference in the case of Philip Moses. ${ }^{60}$ While circle sentencing was initially used for aboriginal offenders, it is now applied to aboriginal and nonaboriginal offenders.

Circle sentencing is an alternative to judges receiving formal sentencing submissions from defence counsel and the prosecution cases involving serious offences or where special circumstances warrant intervention with the offender. ${ }^{61}$ "It is not often used for minor charges, as the process is intrusive, lengthy and requires a significant commitment from all participants". ${ }^{62}$ It has been used for both adults and juveniles. ${ }^{63}$ Circle sentencing cannot be considered a form of diversion because the process results in a criminal conviction and a record for the participating offender. ${ }^{64}$ The offender must normally enter a plea of guilty at an early stage of the proceedings in order to indicate an acceptance of responsibility for the offence. ${ }^{65}$

60 Heino Lilles "Circle Sentencing: Part of the Restorative Justice Continuum" in Allison Morris and Gabrielle Maxwell (eds) Restorative Justice for Juveniles: Conferencing, Mediation and Circles (Hart, Oxford, 2000)

61 Lilles, above, 3.

62 Lilles, above, 3.

63 Lilles, above, 3.

64 Lilles, above, 3.

65 Lilles, above, 3. 
The procedure is as follows. Chairs are arranged in a circle and the session is chaired either by a respected member of the community, sometimes called 'the keeper of the circle' or by the judge. ${ }^{66}$ Unlike other types of restorative justice conferences, sometimes 40 or even 50 people can attend a circle sentencing. The participants in the circle introduce themselves, then the charges are read and the crown and defence lawyers make brief opening remarks. The community members then speak. ${ }^{67}$ Participation is voluntary and everyone has an equal voice. ${ }^{68}$

The focus at circle sentencing is broader than at conventional sentencing hearings and frequently involve discussions of the extent of similar crimes in the community, the causes of these similar crimes, the impact of these crimes on victims and the community in general, what can be done to prevent these kinds of crimes, what will constitute the sentencing plan for this offender, and who will be responsible for making sure that the plan is fully implemented. ${ }^{69}$

Victims are notified in advance that an offender is seeking to use the circle sentencing process. $^{70}$ The victim is assisted in establishing a support group and is encouraged to attend the hearing with his or her support group. ${ }^{71}$

Circle sentencing discussions typically last from several hours up to a full day. ${ }^{72}$ At times, the offender is required to complete a set of tasks or objectives before the circle sentencing process is completed. Circle participants in that instance meet a second time to review the offender's performance and to make any necessary changes to the recommended plan. Finally, the judge imposes a criminal sentence incorporating the recommendations of the circle. ${ }^{73}$

\section{The United States}

Restorative and community justice conferences have been utilised in a number of state and local jurisdictions in the United States. For example, in July 1996, a two-year pilot program using FGCs for juvenile offenders in 12 communities in the 1st Judicial District in Minnesota was begun. ${ }^{74}$ The

66 Lilles, above, 3.

67 Lilles, above, 3.

68 Caroline G Nicholl "Community Policing, Community Justice, and Restorative Justice: Exploring the Links for the Delivery of a Balanced Approach to Public Safety" (Department of Justice, Washington, 1999) 156.

69 Lilles, above, 3-4 and Nicholl, above.

70 Lilles, above, 4.

71 Lilles, above.

72 Lilles, above, 5.

73 Lilles, above.

74 Fercello and Umbreit "Client Evaluation of Family Group Conferencing in 12 Sites in 1st Judicial District of Minnesota" (Center for Restorative Justice and Peacemaking, Minnesota, 1998) 1. 
conferencing used in Minnesota involved a mediation-type process coordinated by a neutral facilitator who assisted victims, offenders and other concerned parties (parents, relatives, friends, and other supporters of the victims or offenders) to engage in an open dialogue about the crime and its impact. ${ }^{75}$

The role of the facilitator was to ensure a safe environment for participants to openly and honestly discuss the circumstances surrounding the crime and the impact. The facilitator was also responsible for making sure that the conference was controlled and fair for all parties involved. ${ }^{76}$ Most conferences began with the facilitator setting down ground rules that allowed each party to have a chance to speak. Next, either the victim or the offender was asked to describe the events surrounding the crime and the impact on him or her. The victim was usually offered a choice as to whether or not he or she would like to speak first or have the offender go first. After the victim and the offender had shared their stories, the facilitator invited the parties to discuss restitution. An important component of the FGC was that both the victim and the offender were required to agree to the restitution before it was finalised. After the restitution agreement was formalised, most conferences ended with participants sharing refreshments. ${ }^{77}$

A separate FGC project was commenced on a local level in November 1995 in Bethlehem, Pennsylvania, a mid-sized American city. The program was dubbed "Operation PROJECT (for "Program for Redirection of Offending Juveniles through Empathy building and Conferencing Techniques") and followed the Wagga model of police-facilitated conferences. ${ }^{78}$ Twenty police officers initially were trained for participation in the program (out of approximately 140 sworn officers). ${ }^{79}$ The program was limited to first-time offenders who had been arrested by police and who had been charged with misdemeanour offences (not including any drug or alcohol crimes). ${ }^{80}$ Participation in the conferencing process was voluntary for both offenders and victims. ${ }^{81}$ Preliminary results showed high rates of satisfaction among victims and offenders. ${ }^{82}$

75 Fercello and Umbreit, above, 2.

76 Fercello and Umbreit, above.

77 Fercello and Umbreit, above.

78 Paul McCold and John Starr "Bethlehem Police Family Group Conferencing Project" (Paper Presented at the Annual Meeting of the American Society of Criminology, Chicago, November 1996).

79 McCold and Starr, above. See also Paul McCold and Benjamin Watchel "Restorative Policing Experiment: The Bethlehem Project (Community Service Foundation, Pipersville, 1998) 3.

80 McCold and Starr, above.

81 McCold and Starr, above.

82 McCold and Starr, above, 4-5. 
Native American Navajos have developed another type of restorative justice practice, the peacemaking circle. Native American Navajos call living in right relationship "Hozhooji". ${ }^{83}$ If a person believes that they have suffered wrongful conduct, they make a demand on the offender to put things right. ${ }^{84}$ If this is unsuccessful, the wronged person may turn to a respected community leader to facilitate and organise a peacemaking circle. ${ }^{85}$ The process is not confrontational but instead involves family and clan members of victims and offenders talking through matters to arrive at a solution. ${ }^{86}$

The process opens with a prayer to seek supernatural assistance. ${ }^{87}$ "Prayer is very powerful in Navajo thinking, because it summons supernatural beings to take part in the process. It actually summons and brings them to the gathering, to participate and to help with the outcome". ${ }^{88}$

Following the prayer, the parties in the circle have an opportunity to explain their grievances. ${ }^{89}$ The victim has an opportunity to disclose not only the facts but the impact of the offence or wrongful conduct as well. ${ }^{90}$ People have an opportunity to say how they feel about the event and to make a strong demand that something be done about it. ${ }^{91}$ Relatives also have an opportunity to express their feelings and opinions about the matter. ${ }^{92}$

The person who is the focus of the discussion is provided an opportunity to explain his or her behaviour in full. ${ }^{93}$ Denials and excuses are exposed by the people who know the wrongdoer best his spouse, parents, siblings, other relatives and neighbours. The process is designed to clarify the offending situation and to get to the root of the problem. The peacemaker has persuasive authority and draws on the traditions and stories of the culture to offer practical advice. The parties then return to a discussion of the nature of the problem and what needs to be done to resolve it. ${ }^{94}$

83 Paul McCold "Restorative Justice Practice: The State of the Field 1999" (Paper presented to the Building Strong Partnerships For Restorative Practices Conference, Burlington VT, Aug 5-7).

84 McCold, above.

85 McCold, above.

86 McCold, above.

87 McCold, above.

88 James W Zion "The Dynamics of Navajo Peacemaking" (1998) 14 J of Contemporary Criminal Justice 7.

89 McCold, above.

90 McCold, above.

91 McCold, above.

92 McCold, above.

93 McCold, above.

94 McCold, above. 
Often, the action taken is in the form of nalyeeh, which also translates as restitution or reparation. ${ }^{95}$ Payments can be in the form of money, horses, jewellery, or other goods. ${ }^{96}$ The payment may at times be symbolic only. The focus is not upon adequate compensation, but upon a holistic kind of remedy. ${ }^{97}$ The feelings and relationships of the parties are what is most important. The process ends in an action plan to solve the problem. ${ }^{98}$

Another type of restorative or community justice process that has been developed is the reparative board, an example of which is the community reparative boards in Vermont, United States. ${ }^{99}$

The process in Vermont commences when a judge sentences a convicted criminal offender involving a minor offence to "reparative probation" in lieu of a traditional probation sentence or brief jail sentence. ${ }^{100}$ After processing and notification to the victim, the offender meets with a board of volunteer community representatives. The meeting is open to the public and begins with a review of the criminal offence, either by the offender or the victim if the victim is present. ${ }^{101}$ The board then explores with the offender what things can be done to repair the injury from the crime and also to reintegrate the offender in the community. ${ }^{102}$ Among the reparative strategies are letters of apology, community service, and further education for the offender. A reparative contract is then prepared and signed by the board and the offender. Offenders who do not fulfil the terms of the contract are returned to the criminal court. ${ }^{103}$

Many have argued that restorative justice should be pursued because traditional court systems have completely failed to stem the rising tide of crime. ${ }^{104}$ Yet, at least in America, crime rates and victimisation rates have been steadily falling - dramatically so - over the last decade. From 1989

95 Robert Yazzie and James W Zion "Navajo Restorative Justice: The Law of Equality and Justice" in Burt Galloway and Joe Hudson (eds) Restorative Justice: International Perspectives (1996) 168.

96 Yazzie and Zion, above.

97 McCold, above.

98 McCold, above.

99 David Karp and Lynne Walther "Community Reparative Boards in Vermont: Theory and Practice" in Gordon Bazemore and Mara Schiff (eds) Restorative Community Justice (Anderson Publishing Co, Cincinnati, 2001) 199.

100 Karp and Walther, above, 200.

101 Karp and Walther, above, 200.

102 Karp and Walther, above, 200.

103 Karp and Walther, above, 200.

104 See, for example, Jim Consedine Restorative Justice: Healing the Effects of Crime (Ploughshares Publications, Lyttleton, 1995) 18-19, 183-184. 
through 1999, crimes recorded by police in the United States fell by more than $18 \%{ }^{105}$ The crime rate (recorded crimes per 100,000 persons) in the United States has similarly declined since 1991. ${ }^{106}$ In 1999 (the last full year for available data), the crime rate in America was the lowest that it had ever been since 1973. ${ }^{107}$ The following table illustrates just how significantly reported crime and crime rates have fallen in the United States in recent years: ${ }^{108}$

CRIME RATE (PER 100,000 PERSONS)

\begin{tabular}{|c|c|c|}
\hline 1970 & $8,098,000$ & $3,984.5$ \\
\hline 1971 & $8,588,200$ & $4,164.7$ \\
\hline 1972 & $8,248,800$ & $3,961.4$ \\
\hline 1973 & $8,718,100$ & $4,154.4$ \\
\hline 1974 & $10,253,400$ & $4,850.4$ \\
\hline 1975 & $11,292,400$ & $5,298.5$ \\
\hline 1976 & $11,349,700$ & $5,287.3$ \\
\hline 1977 & $10,984,500$ & $5,077.6$ \\
\hline 1978 & $11,209,000$ & $5,140.3$ \\
\hline 1979 & $12,249,500$ & $5,565.5$ \\
\hline 1980 & $13,408,300$ & $5,950.0$ \\
\hline 1981 & $13,423,800$ & $5,858.2$ \\
\hline 1982 & $12,974,400$ & $5,603.6$ \\
\hline 1983 & $12,108,600$ & $5,175.0$ \\
\hline 1984 & $11,881,800$ & $5,031.3$ \\
\hline 1985 & $12,431,400$ & $5,207.1$ \\
\hline 1986 & $13,211,900$ & $5,480.4$ \\
\hline 1987 & $13,508,700$ & $5,550.0$ \\
\hline 1988 & $13,923,100$ & $5,664.2$ \\
\hline 1989 & $14,251,400$ & $5,741.0$ \\
\hline 1990 & $14,475,600$ & $5,820.3$ \\
\hline 1991 & $14,872,900$ & $5,897.8$ \\
\hline
\end{tabular}

105 Bureau of Justice Statistics Sourcebook Of Criminal Justice Statistics 1999 (Bureau of Justice Statistics, Washington DC, 2000) 266, Table 3.120, and also see Home Office Statistical Bulletin International Comparisons of Criminal Justice Statistics 1999 (Home Office Statistical Bulletin, Washington DC, 2000) 3, Table A.

106 Bureau of Justice Statistics, above.

107 Bureau of Justice Statistics, above.

108 Bureau of Justice Statistics, above. See also, Bureau of Justice Statistics website: $<$ http://www.ojp.usdoj.gov/bjs >. 


\begin{tabular}{|l|l|l|}
\hline 1992 & $14,438,200$ & $5,660.2$ \\
\hline 1993 & $14,141,800$ & $5,484.4$ \\
\hline 1994 & $13,989,500$ & $5,373.5$ \\
\hline 1995 & $13,862,700$ & $5,275.9$ \\
\hline 1996 & $13,493,900$ & $5,086.6$ \\
\hline 1997 & $13,194,600$ & $4,930.0$ \\
\hline 1998 & $12,475,600$ & $4,615.5$ \\
\hline 1999 & $11,635,100$ & $4,266.8$ \\
\hline
\end{tabular}

It is not just in reported crime that the statistics showed a marked decrease in the United States. Crime victimisation as tallied by the National Crime Victimisation Survey (NCVS) has also shown marked decreases in recent years in America. ${ }^{109}$ In 1999, the total estimate of victimisations in the United States was approximately 28.8 million (with a population of more than 280 million persons). ${ }^{110}$ By comparison, total victimisations in the United States was more than 35 million in 1991 and more than 41 million in 1981. ${ }^{111}$

In 2000, according to the NCVS, crime levels in the United States fell dramatically again. Violent crime victimisations decreased 15\% from 1999 and property crime victimisations decreased $10 \%$ since 1999. ${ }^{112}$ The 25.9 million victimisations recorded in the survey was the lowest number of victimisations ever recorded since 1973, when the NCVS began. ${ }^{113}$

These statistics at least suggest that traditional criminal justice policies have not "failed", at least not in the United States. If restorative justice is to be pursued, there must be other reasons and motivations to justify it. There are. Restorative justice can make critical and important contributions other than simply attempting to supplant an allegedly failed "retributive" criminal justice system. These contributions are discussed below.

109 Bureau of Justice Statistics Sourcebook Of Criminal Justice Statistics 1999 (Bureau of Justice Statistics, Washington DC, 2000) 178, Table 3.1. See Lawrence B Joseph (ed) Crime, Communities and Public Policy (University of Illinois Press, 1995) 39, Table 2.

110 Bureau of Justice Statistics website, above, and Census Bureau Statistics website.

111 Joseph, above.

112 Bureau of Justice Statistics National Crime Victimisation Survey (Bureau of Justice Statistics, Washington DC, 2001) 1, Table 1.

113 Bureau of Justice Statistics, above. 


\section{ADVANTAGES OF RESTORATIVE JUSTICE}

\section{A Victim Participation}

The vast majority of resources in traditional criminal justice systems are focused on the offender. This is not surprising in one sense given the obvious need in the first place to identify offenders.

Once an offender is identified, tremendous resources are expended to ensure that the rights of the accused are protected and not abridged in any way. Police and prosecutors, for example, expend considerable time and effort investigating a matter so that the fact of the crime can be proved beyond a reasonable doubt, the very high standard of proof dictated by the United States Constitution and by law in many other democratic countries around the world, including of course, New Zealand.

As part of the adversary process, the accused is allowed to retain a lawyer or, if financially necessary, a lawyer is appointed to represent the accused in the criminal case. The right to counsel protects all of the due process rights of the accused. The accused has access to the courts with the ability to file motions with the courts to suppress evidence. The accused also has the ability to compel persons to give testimony and to obtain documents and physical evidence in support of the defence. Even more fundamentally, the accused has the right to a public trial before a jury of persons selected from the community. The cost of the jury trial is born entirely by the state.

By contrast, precious few resources are expended by the state on the victim of a criminal offence. ${ }^{114}$ Up until a few years ago, victims were simply sources of information for the police and prosecutors investigating offending conduct. Once a case was filed against an accused, victims became potential witnesses at preliminary court hearings, criminal trials, and sentencing hearings. "Often victims are forced to relive the crime through the interminable processes of the criminal justice system, few resources are available for their own healing, and they remain silenced on the sidelines". ${ }^{115}$ In most American courts, victims do not even have the right to attend the criminal trial until after they have testified in order to protect their testimony from being influenced by the testimony of witnesses testifying before them in the criminal trial.

As part of most sentencing processes, victims are queried by prosecutors or court personnel as part of the preparation of a written victim impact statement that is submitted to the court. Victims rarely have the right to even address the sentencing court orally concerning the impact of the crime

114 See "Offenders Should Pay" (The Dominion, June 8, 2001) 10, "The justice system gives every sign of being designed for the benefit of the offenders and their lawyers rather than the victims. They often seem to be the forgotten people in the process". See also T Richard Snyder The Protestant Ethic and the Spirit of Punishment (W B Eerdmans, Grand Rapids, 2001) 132

115 Snyder, above, 132. 
and restitution issues. "In our experience, victims are rarely involved in the resolution of cases". 116 As a result, "[s]tudies of victims have consistently demonstrated [victims'] frustration and disillusionment with the criminal justice system". ${ }^{117}$

In short, what happens with traditional criminal justice processes is that the victim is virtually forgotten. ${ }^{118}$ Moreover, because of the due process protections afforded to accused persons and offenders and the harsh punitive measures that are frequently assessed against them if they are found or plead guilty, offenders often take on and take over the role of "victim" in conventional criminal justice processes. This is particularly true at sentencing hearings. Judges, probation officers, and defence lawyers focus on the offender as the victim because of the criminal process that the offender has endured and the criminal punishment that that person is about to endure.

In very recent times, small but nevertheless important improvements in the way in which criminal victims are treated have been implemented. In 1990, the United States Congress passed legislation specifically setting out the rights of crime victims. Pursuant to this legislation, the United States Attorney General issued guidelines that implement procedures designed to enhance the treatment of victims by law enforcement investigative agencies (such as the FBI) and United States Attorneys (federal prosecutors). However, Congress specifically denied victims a cause of action to enforce these victims' rights. ${ }^{119}$

Similar measures are being adopted in New Zealand to further protect the rights of victims. ${ }^{120}$ Proposed legislation will give victims the right to be notified of proceedings, to give a victim impact statement at sentencing, and to be informed of services and remedies available. ${ }^{121}$

Restorative justice practices have considerable potential to increase the resources expended on the care and healing of victims. This is because the participation of victims is at the heart of most restorative justice schemes. Indeed, some would argue that a scheme is not really part of the restorative justice "umbrella" unless victims are part and parcel of the process.

116 Douglas B Ammar "Forgiveness and the Law - A Redemptive Opportunity" (2000) 27 Fordham Urban LJ $1347,1591$.

117 New Zealand Department of Justice Victims Court Assistance (New Zealand Department of Justice, Wellington, 1995) 17.

118 Caroline G Nicholl "Community Policing, Community Justice, and Restorative Justice" (1999) 75: "The system is seen to be overprotective of offenders, to isolate victims, and to ignore the fears and concerns of communities"

119 See, 42 USC, $\S 10606(c)$.

120 "Offenders Should Pay" (The Dominion, June 8, 2001) 10.

121 Ministry of Justice Justice Matters (Ministry of Justice, Wellington, 2001) 9 
In restorative justice conferences, a victim is much more than a source of initial information about a criminal offence and a potential witness at trial. The victim is a central actor in the conference. As Judge Heino Lilles remarked regarding the restorative justice process of circle sentencing: "Unlike formal court, where the role of the victim at sentencing is usually limited to providing a victim impact statement, the victim is a full and equal participant in a Circle Sentencing hearing". ${ }^{122}$

Importantly, the victim is allowed and expected to tell an offender directly or through the victim's representative of the harm that was caused by the offending conduct. This can and frequently does have a cathartic effect on the victim. As important, the victim's account of the personal harm that was caused by the offending conduct has proven to frequently be a key ingredient in piercing the shell of the offender and beginning the process of reintegration and restoration for the offender. As Judge Carolyn Henwood, the primary Youth Court Judge in the Wellington City region, recently stated: ${ }^{123}$

[V]ictims are a key participant at the FGC and there can be no doubt [that] when they are present at the conference a better outcome will be achieved. It is my view that a face to face meeting with a victim is the most powerful event that is likely to influence or modify a young person's behaviour.

A frequent outcome of FGCs in New Zealand is an apology from the offender to the victim and the victim's family. This is sometimes given orally at the FGC or sometimes it is given in a letter passed on to the victim at or after the FGC. This apology can be and often is incredibly important to the victim. ${ }^{124}$ Yet it is a component that is most often completely absent from conventional criminal justice processes, even when an offender decides to plead guilty.

Moreover, restoration of the victim by the offender through restitution or other forms of reparation is another central component of restorative justice conferences. Because the harm to victims and their families is a central feature of the conference, it is routine that restitution and similar healing steps are addressed in restorative justice conferences. The parties to a restorative justice conference work toward a consensus as to what will help to restore the victim and often the victim's family as well as what will help to reintegrate the offender. The offender's apology to the victim, his or her agreement to help restore the victim, and then the actual follow-through on those

122 Heino Lilles "Circle Sentencing: Part of the Restorative Justice Continuum" (2000) 4.

123 Judge Carolyn Henwood "The Children, Young Persons and Their Families Act 1989: The New Zealand Situation 1997 - A Judicial Perspective" paper presented to seminar on "Children and the Criminal Law", Judicial Commission of NSW, 1997, 20.

124 See Howard Zehr "Journey To Belonging" 11. "My work with victims suggests that the need for vindication is indeed one of the most basic needs that victims experience; it is one of the central demands that they make of a justice system" $<$ http://www.massey.ac.nz/ wtie/work/journey_to_belonging.htm $>$ (last accessed 22 March 2003). 
agreements then become the building blocks of the offender's own restoration and eventual reintegration into the community. ${ }^{125}$

In these ways, victims are given a new voice in the criminal justice process and the criminal justice process is given a new emphasis: the healing and restoration of victims. As a result, restorative justice is "much more satisfying to victims". ${ }^{126}$

It is perhaps true that victims could be given these kinds of opportunities and these emphases could be added to traditional criminal justice systems. For example, rules and statutes could be (and have in certain instances been) added mandating that victims be given the right to address the court at different stages of the criminal process including sentencing hearings. Restitution to victims could be made mandatory, as it has been by United States law for almost all Federal criminal offences. But these would just be add-ons. Restorative justice practices make healing the victim (through apology, restitution, and so on) a central and fundamental component of criminal justice outcomes.

Additionally, a key part of the restorative justice experience for victims is to view the criminal justice process and the offender "up close". With restorative justice conferences, pre-judgments and media-influenced views held by victims and their supporters fall away to more empathetic and more accurate views of offenders, their families, and the criminal justice system. ${ }^{127}$ One author explained: "Conferencing often demolishes myths and stereotypes about victims and offenders, allowing for a broader meaning of crime, how it can happen, and how it can be prevented". ${ }^{128}$

\section{B Increased Satisfaction}

One notable problem with traditional criminal justice system is the low levels of satisfaction experienced by those participating in it. By contrast, participants in restorative justice processes report relatively high levels of satisfaction.

A study of the restorative justice project in Bethlehem, Pennsylvania reported that the vast majority (over 90\%) of victims, offenders, and offenders' parents would recommend restorative conferencing to others. ${ }^{129} 93 \%$ of victims who participated in the conferences said meeting with

125 Michael Brown "New Zealand Youth Justice Process" <http://www.restorativepractices.org/ Pages/NZ.html $>5$.

126 Judge FWM McElrea "Restorative Process and Outcome: Emerging Theories of Restorative Interventions" paper presented at the Second International Restorative Justice for Juveniles, Fort Launderdale, Florida 7-9 November 1998.

127 Remarks by Chief District Court Judge David Carruthers, (Wellesley Club Luncheon, Wellington, New Zealand, June 6, 2001).

128 Caroline G Nicholl "Community Policing, Community Justice, and Restorative Justice" (1999) 154.

129 Leena Kurki "Restorative and Community Justice in the United States" (2000) 27 Crime and Justice 235. 
the offender was helpful. ${ }^{130} 100 \%$ of participating offenders said meeting with victims was helpful. ${ }^{131} 94 \%$ of victims, $94 \%$ of offenders, and $94 \%$ of parents of offenders would choose to participate in a conference if they had to do it over again. ${ }^{132}$

Similar satisfaction levels were achieved with a group conferencing project in Minnesota. There, $98 \%$ of victims, $94 \%$ of offenders, and $99 \%$ of persons supporting victims or offenders would recommend conferencing to others. ${ }^{133}$ Importantly, $95 \%$ of victims and offenders were satisfied with the outcome of the conference. ${ }^{134}$

In New Zealand, satisfaction levels are fairly high but not in every study. Morris and Maxwell found that $84 \%$ of offenders and $85 \%$ of parents of offenders were satisfied with the outcomes of the FGC. ${ }^{135}$ However, in the Morris and Maxwell study, only about half of the victims participating in FGCs reported being satisfied with the outcome of the conference. ${ }^{136}$ About 31\% of victims were dissatisfied with the outcome of the $\mathrm{FGC}$, an interesting statistic given that victims can reject a FGC agreement with which they disagree. ${ }^{137}$

On the other hand, other researchers have found much higher levels of satisfaction experienced by victims who participated in FGCs. Marion Ellis interviewed victims who participated in FGCs in late 1996 and early 1997 in Dunedin. ${ }^{138}$ Ellis found that over 92\% of responding surveyed victims were "satisfied" or "very satisfied" with the FGC that they attended. ${ }^{139}$ Moreover, $95 \%$ of victims indicated that the FGC has "met their expectations". 140 Finally, $85 \%$ of surveyed victims indicated that they felt better after the conference than before. None of the surveyed victims felt

130 Paul McCold and Benjamin Wachtel "Restorative Policing Experiment: The Bethlehem Police Family Group Conferencing Project" (1998) 3.

131 McCold and Wachtel, above.

132 McCold and Wachtel, above.

133 Claudia Fercello and Mark Umbreit "Client Evaluation of Family Group Conferencing in 12 Sites in 1st Judicial District of Minnesota" (1998) <http://sssw.che.umn.edu/rjp/Resources/Documents/ferumb98.pdf> 1 .

134 Fercello and Umbreit, above.

135 Allison Morris and Gabrielle Maxwell "Restorative Justice in New Zealand: Family Group Conferences As A Case Study" (1998) 1 Western Criminology Review, 11.

136 Morris and Maxwell, above, 12.

137 Morris and Maxwell, above, 11.

138 Marion Ellis "Victims, Restorative Justice, and the New Zealand Family Group Conference" (2000) 72-73.

139 Ellis, above, 89.

140 Ellis, above, 112. 
worse after the conference while $10 \%$ felt about the same after the conference. ${ }^{141}$ The most common reason for feeling better after the conference was the remorse shown or expressed by the offender. $^{142}$

In Australia, researchers have found high levels of satisfaction among conference participants. In New South Wales, a 1999 study found over $90 \%$ of participants felt that the conference was fair to both victim and offender. ${ }^{143}$ Over $90 \%$ felt that had the opportunity to express their views and had been treated with respect, and at least $79 \%$ said they were satisfied with the way their case had been dealt with by the justice system. ${ }^{144}$

\section{Acceptance of Responsibility}

Judge FWM McElrea of the Youth Court in Auckland has commented: "The western model of criminal justice does not in my view hold offenders accountable in a meaningful way". ${ }^{145}$ Van Ness and Strong have explained it this way: ${ }^{146}$

Because of the legal presumption of innocence bestowed on all defendants, as well as the panoply of due process rights that are afforded them, defendants have few incentives to assume responsibility for their actions, and many incentives to remain passive while the government marshals its cases and [defence] lawyers attempt to dismantle them.

Judge McElrea quoted the astute comments of the Saskatchewan Deputy Minister of Justice, Brent Cotter, who stated at a Restorative Justice Conference in March 1995: ${ }^{147}$

The [traditional] criminal justice system encourages you to avoid responsibility and deny, and hope you might get off. In a family, such behaviour would be considered dysfunctional. In a community it is still dysfunctional.

Not only do offenders refuse to plead guilty even when they have committed the offence with which they are charged but even those offenders who choose to plead guilty are most often not fully held accountable. Frequently, they do not own up forthrightly and completely to the factual

141 Ellis, above, 114.

142 Ellis, above, 114-115.

143 Heather Strang "Restorative Justice Programs in Australia" (2001) $9<$ <ttp://www.aic.gov.au/ cre/reports/strang/index.html $>$.

144 Strang, above.

145 Judge FWH McElrea (ed) "Accountability in the Community: Taking Responsibility for Offending" in ReThinking Criminal Justice Vol I (Legal Research Foundation, Auckland, 1995) 64.

146 Daniel Van Ness and Karen Heertderks Strong Restoring Justice (Anderson Publishing Co, Cincinnati, 1997) 31.

147 Judge McElrea, above, 67. 
circumstances of the offence and rarely do they apologize or otherwise make amends to the victim. As Howard Zehr (quoted by McElrea) stated regarding the traditional criminal justice system: ${ }^{148}$

You do your time in prison and you're paying your debt to society, but it doesn't feel like you're paying a debt to anybody - basically, you're living off people while you are doing that. You never in that process come to understand what you did, and what I'm saying "accountability" means is understanding what you did and then taking responsibility for it; and taking responsibility for it means doing something to make it right, but also helping to be part of that process.

Restorative justice conferences along with other restorative processes can encourage offenders to accept responsibility more often and more fully in several ways. Because restorative justice processes can shift the primary emphasis from punishment to accountability, restoration, and healing, offenders will be able to discover that the critical step in their own healing and reintegration is acknowledging responsibility for what they have done. ${ }^{149}$

The absence of technical jargon (for example, regarding the admissibility of evidence and regarding burdens of proof) at a restorative justice conference also assists offenders in forthrightly and candidly owning up to what they did and why. It is often easier to get at the truth of what happened without the full panoply of procedural rules embodied in the traditional, court-based system of justice.

\section{Decreased Recidivism}

Research over the past several years indicate significant potential for restorative justice programs to reduce recidivism. In one study, researchers from the Institute of Criminology of Victoria University and researchers from the Ministry of Justice studied the effects of restorative justice conferencing of "Project Turnaround" in Timaru, New Zealand. ${ }^{150}$ As noted above, Project Turnaround used restorative conferences convened by a community panel with the input of crime victims. Researchers looked at the "if", "when", and "how" persons who were participants in Project Turnaround were re-convicted of a criminal offence as compared with a closely matched control group. The researchers found that the Project Turnaround group were re-convicted less often and that the difference in re-offending rates between the two groups was statistically significant one year after participation in the restorative conference. ${ }^{151}$ Researchers also found that

148 Judge McElrea, above, 64.

149 Judge McElrea, above, 68.

150 Gabrielle Maxwell, Allison Morris, and T Anderson Community Panel Adult Pre-trial Diversion: Supplementary Evaluation (Department of the Prime Minister and Cabinet/Institute of Criminology, Victoria University, Wellington, 1999).

151 Maxwell, Morris, and Anderson, above, 43-44. 
the offences of which the Project Turnaround participants were re-convicted were less serious than those of the control group who were not part of the restorative justice process. ${ }^{152}$

These same researchers studied another restorative justice scheme in West Auckland named "Te Whanau Awhina". This restorative justice scheme was Maori-based and differed in the specific processes utilised. Reductions in recidivism were observed there as well, both in reconviction rates and seriousness of re-offending. ${ }^{153}$

Research into the impact of restorative justice conferences using control groups was also done in Canberra, Australia by researchers from the University of Pennsylvania and from the Australian National University. Researchers found that restorative conferences for those youths involved in violent crime reduced reoffending rates by a larger percentage: 38 crimes per 100 offenders per year (as compared to simply being sent to court). ${ }^{154}$ However, it should be noted that similar reductions in recidivism rates were not observed with respect to youths involved in drunk driving or juvenile property crimes. ${ }^{155}$

One of the better explanations for why restorative justice processes appear to be more effective in reducing recidivism than traditional criminal justice processes in court has been put forward by Charles Barton. Barton sets out in an article entitled "Theories of Restorative Justice" four explanations for why restorative justice processes work: ${ }^{156}$

1. Reversal of moral disengagement: (re)engaging the offender at a moral psychological level with the consequences of their behaviour.

2. Social and moral development: aiding the moral and social development of the offender, so that they can learn and become wiser for the experience.

3. Emotional and moral psychological healing: aiding emotional and moral psychological healing from the trauma of the criminal incident through interaction between the parties and symbolic reparation.

4. Re-integrative shaming: tempering unequivocal disapproval of the wrongful behaviour (shaming) with expressions of respect and acceptance of the individual into their community (reintegration).

152 Maxwell, Morris, and Anderson, above, 50.

153 Maxwell, Morris, and Anderson, above, 5, 45, and 50.

154 Australian National University, above, 12.

155 Australian National University, above. See also Heather Strang "Restorative Justice Programs in Australia" (2001) $38<$ http://www.aic.gov.au/crc/reports/strang/index.html $>$.

156 Charles Barton "Theories of Restorative Justice" (2000) 1 Australian Journal of Professional and Applied Ethics 3. 
It is an observed phenomenon that, when persons engage in conduct harmful toward another person, they ease or silence their consciences by various means of moral disengagement including: blaming or de-humanising the victim, rationalising that the good consequences from the conduct outweigh the bad, denying the seriousness of the harmful effects on others, and obscuring or lessening personal responsibility for the wrongful activity. ${ }^{157}$ Well-run restorative justice conferences, "where affected people tell the offender face to face about the disruption and harm their actions caused", seriously challenge and often successfully reverse internal mechanisms of disengagement. ${ }^{158}$

Barton believes that even recidivists can be influenced for the better with restorative processes. ${ }^{159}$ Pointing to research that crises can be converting, Barton argues that there is "no better way to induce and guide the outcome of such crises than in a restorative justice meeting, such as a conference or a sentencing circle where important people in the life of the offender are active participants". 160 "When, in addition to the victim and their supporters, the most important people in the offender's life confront the offender with their unacceptable behaviour and make it clear that they are shocked, hurt, and ashamed by it, and that it is intolerable, there is tremendous pressure on the offender to re-examine their moral outlook and the kind of person they want to be". ${ }^{161} \mathrm{~A}$ key, Barton emphasises, is that this pressure is applied in an overall supportive and caring environment. ${ }^{162}$

It is important that restorative justice processes emphasise reintegrative as opposed to destructive shaming. Numerous studies have shown that condemning the criminal conduct while acknowledging the fundamental worth of the offending person is much more effective in reducing the chance for recidivism than is shaming or stigmatizing the offender because he has engaged in criminal conduct. ${ }^{163}$

\section{E Problem-solving Approach to Crime}

It is true that restorative justice conferences are in the first instance concerned with dealing with the aftermath of offending conduct principally from the perspectives of the victim and the offender.

157 Barton, above, 3-4.

158 Barton, above, 4.

159 Barton, above, 7.

160 Barton, above, 9.

161 Barton, above, 9 .

162 Barton, above, 9.

163 See, for example, Maxwell and Morris Understanding Reoffending (Institute of Criminology, Victoria University, Wellington, 1999) 41. 
Yet experience with restorative justice conferences in New Zealand has shown an ancillary benefit from restorative conferencing.

FGCs in New Zealand, for example, have provided a greater understanding of why and how youth crime is committed. This is not surprising given the frank discussions that are engendered at FGCs. Frequently, as noted above, victims want to know "why me?" or how did the crime itself come to happen. ${ }^{164}$ Also, details regarding why and how the crime was committed are needed in order to put together an appropriate response to the offender's criminal conduct. In the course of answering these questions, participants to the conference including youth justice co-ordinators and police learn significant information about what is happening in the community and why it is happening. ${ }^{165}$ Police and other criminal justice agencies can then use this information to "problem solve" and target specific preventative or curative action. ${ }^{166}$

In Wellington, New Zealand, for example, police and the youth justice co-ordinator learned in part from FGCs some of the factors underlying the criminal conduct by repeat offenders. What they found was that these youths were often culturally isolated and/or had suffered a major trauma in their childhood. As a result, these youths aligned themselves to questionable role models, including role models in criminal gangs. The police and the local youth justice co-ordinator also found out that repeat youth offenders tended to offend together (or in groups) and had a history of truancy.

Using this information and a police problem-solving approach, the youth aid police and the youth justice co-ordinator in Wellington worked with local schools and community groups to address several key causes and factors involved in the worst and most troublesome youth offending in Wellington. In particular, a program called Tu Rangitahi was developed in ordered to address repeated criminal offending by a group of youths associated with the Black Power gang. ${ }^{167}$ Another program in the second half of 2000 targeted 15 Samoan youths from the Newtown area of Wellington who were known to police and the youth justice co-ordinator for their criminal behaviour. ${ }^{168}$ Both of these programs provided activities that were aimed at enhancing the self-

164 Michael J A Brown "New Zealand Youth Justice Process" <http://www.restorativepractices.org/ Pages/NZ.html $>4$

165 Judge Carolyn Henwood "The Children Young Persons and Their Families Act 1989: The New Zealand Situation 1997 - A Judicial Perspective" (1997) 47

166 Caroline G Nicholl "Community Policing, Community Justice, and Restorative Justice" (Department of Justice, Washington, 1999) 154-155 and Paul McCold and Benjamin Wachtel "Community Is Not A Place: A New Look At Community Justice Initiatives" (1998) 1 Contemporary Justice Review 71, 79. "The collaborative processes developed from restorative justice practitioners are a natural tool for police interested in engaging communities for crime control and prevention...".

167 Chief District Court Judge David Carruthers "Restorative Justice, With Reference To Experience In New Zealand" $16^{\text {th }}$ Biennial District and County Judges' Conference, Adelaide, paper provided to the author, $2001,9$.

168 "When Bad Boys Turn Out Good" The Dominion, October 5, 2000. 
worth of the young persons who were being recruited by gangs. The programs also worked to build cultural links and awareness of community support. ${ }^{169}$

A third program initiated in Wellington City focused on truancy and suspensions from school involving at-risk youths. ${ }^{170}$ Police working with the Wellington justice co-ordinator found that crimes were being committed by young persons who had been suspended from school or who had otherwise dropped off school rolls. Working with schools, the police and the justice co-ordinator developed alternatives to school suspensions, including drug and alcohol counselling and anger management courses. The result was a major drop in school suspensions and a major decline in referrals to police. ${ }^{171}$

The overall results of this problem solving approach in Wellington, based in part on the "intelligence" and understanding gathered in the FGCs, was nothing short of spectacular. ${ }^{172}$ Between 1996 and 2000, youth offending in Wellington decreased by two-thirds. Specifically, in 1996, police and the Department of Child, Youth and Family Services conducted 556 youth justice FGCs in Wellington. By the year 2000, only 174 FGCs needed to be held. In considering this decline, it is important to remember that FGCs are mandatory in New Zealand if a youth is going to be charged with a criminal offence other than murder or manslaughter. ${ }^{173}$

\section{F Some Additional Strengths}

As noted above, a principal aim of the legislation that was passed as the Children, Young Persons and Their Families Act of 1989 was to introduce a greater cultural sensitivity and accommodation to the tangata whenua. Researchers who have studied the Act and the FGC process have acknowledged that there is at least a considerable potential for cultural and ethnic accommodation. ${ }^{174}$ The key to cultural accommodation with conferencing appears to be flexibility.

169 "When Bad Boys Turn Out Good", above.

170 Chief District Court Judge Carruthers, above, 9-10.

171 Chief District Court Judge Carruthers, above, 9.

172 Chief District Court Judge Carruthers, above, 10.

173 See Children, Young Persons and Their Families Act 1989, ss 272-274.

174 Olsen, Maxwell, and Morris "Maori and Youth Justice in New Zealand" in Kayleen M Hazlehurst (ed) Popular Justice and Community Regeneration: Pathways of Indigenous Reform (Praeger, Westport, 1995). See also Paul Nixon "Family Group Conference Connections: Shared Problems and Joined Up Solutions" (1999) 2; Judge Carolyn Henwood "The Children Young Persons and Their Families Act 1989: The New Zealand Situation 1997 - A Judicial Perspective" (1997). Paper presented at the Building Strong Partnerships for Restorative Practices Conference, 5-7 August 1999, Burlington, Vermont. Available online at $<$ http://www.restorativepractices.org/pages/vt_nixon.html $>46$. 
As Luna said of the FGC in New Zealand, a restorative justice conference is "an inherently flexible process". 175

Giving stakeholders in the criminal justice process such as victims, offenders and community groups new voices and power to make decisions seems to be additional keys to cultural accommodation. A concomitant part of this new design, however, is that the state and other actors in the traditional criminal justice system must be willing to relinquish their exclusive hold on the justice process and turn over real decision-making power to these other stakeholders. As one author recently put it: "Core restorative ideals imply that government should surrender its monopoly over responses to crime to those who are directly affected - the victim, the offender, and the community". 176

An important component of restorative justice is that decisions should be reached through personal dialogue and consensus. ${ }^{177}$ Kay Pranis of the Minnesota Department of Corrections has written of the importance of giving those centrally involved in the criminal justice process a voice and allowing them to reach decisions through consensus: that is democracy in action on a small scale, but with enormous implications if practised widely. ${ }^{178}$

It is a hallmark of restorative justice that decisions about how to deal with the aftermath of crime are reached after the views of all participants have been canvassed and considered. After this consideration and collaboration, a group decision emerges and is implemented. In this way, it is possible for larger groups (offenders, victims, and police) to feel "ownership" of the conference outcome.

Judge Barry Stuart, the first Canadian judge to use a sentencing circle, has emphasised that a key component of restorative justice processes is the building up of communities, "changing

175 Erik Luna "Reason and Emotion in Restorative Justice", paper provided to author, 2001, 12. See also Heino Lilles "Circle Sentencing: Part of the Restorative Justice Continuum" monograph provided to the author, $2000,23$.

176 Leena Kurki "Restorative and Community Justice in the United States" (2000) 27 Crime and Justice 235. See also Daniel Van Ness and Karen Heertderks Strong Restoring Justice (Anderson Publishing Co, Cincinnati, 1997) 31.

177 Kurki, above, 239.

178 Kay Pranis "Conferencing and the Community", paper presented at the First North American Conference on Conferencing, 6-8 August 1998, Minneapolis, Minnesota. Available online $<$ http://www.restorativepractices.org/Pages/Library.html $>$ 8. See also John Braithwaite "Restorative Justice" in Michael Tonry (ed) The Handbook of Crime and Punishment (Oxford University Press, New York, 1998) 329. 
perspectives about what communities can do, and forging new, cooperative working relationships". 179

Tony Marshall has commented as well: "Restorative Justice programmes mobilise community resources (voluntary organisations, volunteer mediators), enhance community capacities for social control (conflict-resolution, education, prejudice-reduction, experience of collaborative problemsolving, etc) and directly create opportunities for offender support and reform (eg conferencing programmes)". ${ }^{180}$ The recruitment of volunteers from the community has been a part of this community building. "Restorative justice programs have been successful in involving volunteers". ${ }^{181}$

In New Zealand, successful youth justice practices are most often characterised by youth justice co-ordinators who are aware of existing community resources and are working to build additional community-based resources for offenders and victims. ${ }^{182}$ Indeed, the title "youth justice coordinator" suggests the active co-ordination of youth justice resources from both the state and the local community.

\section{G Spirituality}

One New Zealander, Tom Marshall, has emphasised that true healing and forgiveness cannot be achieved without the intervention of God. ${ }^{183}$ Canadian Judge Barry Stuart has written that people experience conflict in four dimensions: mental, emotional, physical and spiritual. ${ }^{184}$

Restorative justice processes and certainly conferences in particular are flexible and dynamic enough to create a space for the spirituality that strengthens or in some people's view enables healing and restoration. In New Zealand, for example, FGCs are often begun with a prayer or

179 Barry Stuart "Guiding Principles for Peacemaking Circles" in Gordon Bazemore and Mara Schiff (eds) Restorative Community Justice (2001) 235. See also Paul H Hahn Emerging Criminal Justice: Three Pillars for a Proactive Justice System (Sage Publications, Thousand Oaks, 1998) 133.

180 Tony F Marshall "Restorative Justice: An Overview" (HMSD, London, 1999) 21.

181 Leena Kurki "Restorative and Community Justice in the United States" (2000) 27 Crime and Justice 235.

182 Judge Carolyn Henwood "The Children Young Persons and Their Families Act 1989: The New Zealand Situation 1997 - A Judicial Perspective" paper presented to seminar on "Children and the Criminal Law", Judicial Commission of NSW, 1997, 23.

183 See Tom Marshall Right Relationships (Sovereign World International, London, 1989) 90.

184 Barry Stuart "Guiding Principles for Peacemaking Circles" in Gordon Bazemore and Mara Schiff (eds) Restorative Community Justice (2001) 233. 
karakia (Maori prayer). In America, Navajo peacemaking circles "with a prayer to seek supernatural assistance". ${ }^{185}$

\section{H Improved Perceptions of Police}

In many areas and among many groups, perceptions about police have declined substantially. Many, particularly among minority populations, are distrustful and fearful of the police. Some have attributed this distrust to the emergence of police "professionalism". ${ }^{186}$

Whatever the cause, restorative justice has the potential to change and improve on the public's perception of the police, perhaps even dramatically so. Preliminary data from Canberra, Australia, for example, suggests that offenders have much more positive perceptions of police following participation in a restorative conference than following traditional court processes. In about $90 \%$ of cases assigned to a conference, offenders thought that the police had been fair to them. In cases randomly assigned to court, only 48 to $78 \%$ of offenders thought that the police had been fair. ${ }^{187}$

One reason for the improved perceptions in police performance from restorative justice processes is that police almost inevitably gain deeper and truer understandings of their community through their participation in restorative justice processes. Restorative justice conferences allow for candid interactions between the police, offenders, offenders' families, and victims that provide the police with greater insights into why and how crimes have been committed. Police can in turn use this information to respond more appropriately in their communities.

Additionally, restorative justice conferences allow the police to propose, support, and agree to less onerous punishments for offenders. In this way, police are frequently viewed by offenders and offenders' families as having empathetic and even sympathetic views. As one author noted: ${ }^{188}$

The relationship between the police and the community, especially, can be strengthened through conferencing. Participants who are invited ... to attend a conference are inclined to think more positively and favourably toward the police simply because of the willingness by the police to listen and allow their views to shape decision-making. . . People also feel better about being involved in a process

185 Paul McCold "Restorative Justice Practice - The State of the Field 1999", paper presented at the Building Strong Partnerships for Restorative Practices conference 5-7 August 1999, Burlington, Vermont, available at $<$ http://www.restorativepractices.org/pages/library.html\#principles $>$ ) 15.

186 See, for example, Craig D Uchida "The Development of the American Police: An Historical Overview" in Paul Cromwell and Roger Dunham (eds) Crime and Justice in America: Present Realities and Future Prospects (Englewood Cliffs, New Jersey, 1997) 92.

187 See John Braithwaite "Restorative Justice: Assessing Optimistic and Pessimistic Accounts" in Michael Tonry (ed) Crime and Justice: A Review of Research vol 25 (University of Chicago Press, Chicago, 1999) 102.

188 Caroline G Nicholl "Community Policing, Community Justice, and Restorative Justice" (1999) 154-150. 
that inspires community building, and promotes healthy community relationships, than they do about attending an adversarial trial that tends to leave people feeling sour.

Improved perceptions of police not only allow police to gather information more effectively but also appears to directly reduce the crime rate. "[R]esearch consistently demonstrates that individuals who believe that the police treated them fairly and respectfully in their previous encounters are more likely to obey the law in the future". ${ }^{189}$

\section{Cutting Across Political Lines}

Commentators have recognised the potential for restorative justice to cut across traditional political lines. Professor John Braithwaite has noted that restorative justice appeals to liberal politicians as a less punitive system while appealing to conservatives through its strong emphasis on victim empowerment, family empowerment, and increased personal responsibility. ${ }^{190}$ Other commentators as well have noted that restorative justice can accommodate both "law and order" and "progressive" responses to crime. ${ }^{191}$

\section{SOME CONCERNS ABOUT RESTORATIVE JUSTICE}

\section{A Soft on Offenders}

Among some, there has been an impression that restorative justice processes are too lenient or "soft" on criminal offenders. ${ }^{192}$ These concerns can be answered in several ways.

As an initial matter, restorative justice processes and outcome are not easy or "soft". Researchers have found based on observations of restorative justice processes and with interviews of offenders after these processes that facing a victim is most often a difficult and emotional experience for offenders. ${ }^{193}$ Offenders, in the face of real suffering by real victims, are less able to utilise excuses to explain away or rationalise their offending behaviour. Many offenders have indicated that restorative justice processes and outcomes are more difficult to endure than traditional justice processes and punishment. ${ }^{194}$

189 Philip B Heymann "The New Policing" (2000) 28 Fordham Urban Law Journal 407, 419.

190 John Braithwaite "Restorative Justice: Assessing Optimistic and Pessimistic Accounts" in Michael Tonry (ed) Crime and Justice: A Review of Research vol 25 (University of Chicago Press, Chicago, 1999) 4.

191 See Kathleen Daly "Revisiting the Relationship between Retributive and Restorative Justice" in Strang and Braithwaite (eds) Restorative Justice: Philosophy to Practice (Ashgate, Aldershot, 2000) 34. See also Nicholl, above, 149, citing the bipartisan support for restorative justice conferencing.

192 Tony F Marshall "Restorative Justice: An Overview" (HMSD, London, 1999) 26.

193 Marshall, above, 19.

194 Marshall, above, 19. 
It is not only the personal meeting with victims and hearing from victims that are difficult for offenders. Restorative justice is tougher on offenders because active acceptance of responsibility for the criminal conduct and for putting things right for the victim and the community is expected of offenders. ${ }^{195}$

The Chief District Court Judge of New Zealand has observed: ${ }^{196}$

There is nothing soft about the way conference participants deal with offenders. In fact, my experience

is that, in terms of outcomes, the courts are and have been much softer on young offenders than families

ever are. "Sometimes it's an easy option for a youngster to go into prison for a short time and sit in his

cell doing nothing for the greater part of the day".

\section{B Net-Widening}

Another criticism levelled at restorative justice processes is that they expand the types and numbers of offenders who are involved in the justice process and thereby expand the intrusion of governmental authority. ${ }^{197}$

The usual response to the net-widening criticism is to cite research that shows that restorative justice does not result in net-widening. Maxwell and Morris, for example, studied the use of FGCs and the diversionary scheme contained in the Children, Young Persons and Their Families Act of 1989. They found that a lack of any net widening through the use of FGCs in New Zealand and that, since the Act was passed, overall "young people are now much more likely to be dealt with by informal means, within the community, and without a record of a conviction". 198 Other researchers have similarly found no net widening effects. ${ }^{199}$

195 Marshall, above, 26.

196 Chief District Court Judge David Carruthers "Restorative Justice, With Reference To Experience In New Zealand" $16^{\text {th }}$ Biennial District and County Judges' Conference, Adelaide, paper provided to the author, 2001,9 .

197 See, for example, Richard Delgado "Goodbye to Hammurabi: Analyzing the Atavistic Appeal of Restorative Justice" (2000) 52 Stanford Law Review 751, 761-762; and Martin Wright Justice for Victims and Offenders: a Restorative Response to Crime (Waterside Press, Winchester, 1996) 156.

198 Gabrielle Maxwell and Allison Morris "Research on Family Group Conferences with Young Offenders in New Zealand" in Joe Hudson, Allison Morris, Gabrielle Maxwell, and Burt Galaway (eds) Family Group Conferences: Perspectives on Policy and Practice (1996) 94.

199 See generally John Braithwaite "Restorative Justice: Assessing Optimistic and Pessimistic Accounts" in Michael Tonry (ed) Crime and Justice: A Review of Research: vol 25 (University of Chicago Press, Chicago, 1999) 89; collecting research. 
Others have responded to the net-widening concern by noting that restorative justice processes, by empowering victims, family members and community representatives, in fact reduce state power and control. ${ }^{200}$

From a different perspective, given the positive contribution that restorative justice processes can have (on offenders, victims, and communities), one may argue that net-widening effects do not constitute an unwelcome by-product of restorative justice but an improvement. As one scholar put it recently, "an assumption that net widening is a bad things seems wrong". ${ }^{201}$ The argument here would be that, by dealing with offenders earlier and with less serious offences, we have a better chance to re-integrate the offender into the community and with less cost to the community. The alternative is to wait until persons have committed more serious offences and caused greater harm to victims, the community, and to themselves.

In Wellington, New Zealand, for example, police youth aid officers use FGCs (following consultations with the local youth justice co-ordinator) to deal with somewhat minor offences (fighting, shoplifting, and so on) in order to prevent young persons from committing more serious offences such as assault, burglary, and robbery. In these instances, police youth aid give notice of their intention to charge young persons with certain criminal offences in order to have a FGC scheduled. If the FGC agreement and plan is adhered to by the young person, and statistics show that it usually is, then police do not follow up the matter with formal charges and the matter never proceeds to court adjudication. By intervening at an earlier stage, the police and the youth justice co-ordinator in Wellington City have helped to reduce crime rates in the area substantially since 1996.

\section{Outcome Disparity}

A frequently-noted concern about restorative justice is that it may lead to outcome disparity, that is, offenders involved in like offending end up with different sanctions. ${ }^{202}$ This concern was also recently raised by the Chief Justice of New Zealand, the Right Honorable Dame Sian Elias. In an April 24, 2001 lecture in Napier, the Chief Justice expressed support for the aims of restorative justice programs but simultaneously expressed concerns including the concern that "consistency of treatment of like cases" may be jeopardised in restorative justice schemes. ${ }^{203}$ As the Chief Justice noted, fundamental fairness would seem to suggest that persons who have engaged in the same kind

200 See, for example, Erik Luna "Reason and Emotion in Restorative Justice", paper provided to author, 2001, 11; and Braithwaite, above, 90-91.

201 Braithwaite, above, 91.

202 See, for example, Richard Delgado "Goodbye to Hammurabi: Analyzing the Atavistic Appeal of Restorative Justice" (2000) 52 Stanford Law Review 751, 759.

203 The Chief Justice of New Zealand, the Right Honorable Dame Sian Elias, GNZM, "Lecture on the Occasion of the John Robson Lecture for the Napier Pilot City Trust" (April 24, 2001) 3. 
of criminal conduct should receive roughly the same criminal justice sanction. The Chief Justice said that, "without such consistency corrosive unfairness can result". 204

The responses to concerns about inconsistency from restorative justice practices have been addressed in several ways. Some have argued essentially that there has been inconsistency in sentences in traditional criminal justice systems and consistency is not a paramount criminal justice value anyway. ${ }^{205}$ These kinds of responses, however, seem to ignore the common-sense notion that offenders who commit similar offences ought to be sanctioned similarly as well as the fact that certain kinds of traditional criminal justice schemes (for example, that of the United States under the Sentencing Guideline system since 1987) have achieved high levels of sentencing consistency.

A better response to the consistency concern is to achieve as much consistency as possible and then to justify adequately any remaining inconsistency. As the author explained elsewhere, incorporating restorative justice processes within a sentencing guideline system may help to achieve a substantial measure of consistency. ${ }^{206}$ Any remaining disparities can be justified by circumstances that are unique to each individual case.

Another response to the concern about inconsistency is to give the courts a supervisory role over the outcomes decided upon through restorative justice conferences and other practices. "In fulfilment of this role, the Court can safeguard against discriminatory results". ${ }^{207}$

\section{Potential Re-victimisation}

Because of the central role played by victims at restorative justice conferencing and other restorative justice programs, an obvious concern is that victims may be harmed further by participating in restorative justice processes. ${ }^{208}$ It is a weighty concern. ${ }^{209}$ Re-victimisation of persons who have already suffered physical harm, disrespect, loss of control, pecuniary loss, and more from the criminal offence itself would be unacceptable. It is worth noting however that the

\footnotetext{
204 The Chief Justice, Sian Elias, above.

205 See Allison Morris and Warren Young "Reforming Criminal Justice: The Potential of Restorative Justice" in Heather Strang and John Braithwaite (eds) Restorative Justice: Philosophy to Practice (2000) 21-22.

206 Donald J Schmid "Restorative Justice in New Zealand: A Model for US Criminal Justice" $<$ http://www.fulbright.org.nz/voices/oxford/schmidd.html $>$ 53-57.

207 Remarks by Chief District Court Judge David Carruthers "Restorative Justice, With Reference To Experience In New Zealand" $16^{\text {th }}$ Biennial District and County Judges' Conference, Adelaide, paper provided to the author, 2001, 12 .

208 Heather Strang "Restorative Justice Programs in Australia" (2001) 35-36 $<$ http://www.aic.gov.au/crc/reports/strang/index.html $>$.
}

209 Chief District Court Judge Carruthers, above, 18. "This is not a criticism that can be dismissed lightly". 
New Zealand Victim Support Agency has, despite the possibility of re-victimisation, endorsed the restorative justice approach. ${ }^{210}$

Steps can be taken to reduce the possibility of the justice process further injuring victims. ${ }^{211}$ Surveyed justice co-ordinators in New Zealand almost all felt that effective steps could be taken that would avoid victims being re-victimised at the FGC. Co-ordinators cited the ability of victims to have support at the conference as one such measure. Other protective measures included careful preparation in advance of the conference of both offenders and victims to ensure that the rights of victims were well understood and that victim expectations were realistic. Co-ordinators also cited the presence of police as well as the control exerted by the co-ordinator at the conference as steps that helped ensure that victims were not intimidated or otherwise re-victimised at the FGC. Finally, co-ordinators frequently cited the veto power that victims had over the FGC plans or agreements as a way for victims to avoid being re-victimised.

\section{E Offenders' Rights}

Some have argued that an offender's fundamental rights of due process are likely to be infringed through restorative justice practices. ${ }^{212}$ The argument is basically that, because lawyers are not always present and do not manage the process, an offender's basic rights may be overlooked or otherwise forfeited.

The Chief District Court Judge of New Zealand has responded directly to this criticism: ${ }^{213}$

While it is desirable that offenders be encouraged to speak for themselves, there is no necessity to exclude lawyers from the restorative justice conference process. In this context, it is appropriate that the lawyer fulfil the role of protecting the offender's basic rights in a manner consistent with the objectives of restorative justice. This requires an understanding, on the part of lawyers, of the difference of their role under the restorative justice process.

A survey of youth justice co-ordinators in New Zealand in May-June 2001 by the author revealed that lawyers in New Zealand who represent juvenile offenders (called "youth advocates") are fulfilling their role well. That is, most justice co-ordinators see youth advocates who participate in FGCs as protecting the basic due process rights of their clients well while at the same time playing a constructive role in the restorative justice process that requires different approaches than that required in the adversary criminal justice system.

210 Chief District Court Judge Carruthers, above.

211 Chief District Court Judge Carruthers, above.

212 See, for example, Richard Delgado "Prosecuting Violence: A Colloquy on Race, Community, and Justice" (2000) 52 Stanford L Rev 751, 753, 760.

213 Chief District Court Judge Carruthers, above, 19. 


\section{CONCLUSION}

Commentators have noted that restorative justice programs are unable to replace traditional court-based criminal justice systems entirely. ${ }^{214}$ Rather, there is real potential for restorative justice programs to exist alongside court-based criminal justice systems.

As Father Jim Consedine wrote in the Foreword to the New Zealand Restorative Justice Practice Manual: 215

Restorative justice is a positive way of dealing with crime. It can lead to the transformation of people's lives. The question is - do we have the courage, the vision, and the political will to implement it? ...

The answer rests with us all.

No one can doubt that we can do better in responding to crime, in caring for victims of crimes, and in making our communities more respectful and safer places in which to live. Restorative justice presents a new paradigm in criminal justice policy. It is a paradigm that is gaining increased acceptance around the world. That paradigm is gaining increased acceptance because the people who are involved with restorative justice and the researchers who have studied restorative justice programs know of its effectiveness and transformative potential.

214 See, for example, John Braithwaite "A Future Where Punishment Is Marginalised: Realistic or Utopian?" (1999) 46 UCLA L Rev 1727, 1742.

215 Bowen, Boyack, and Hooper New Zealand Restorative Justice Practice Manual (2000) 10. 
